\title{
Chemical constituents and pharmacological profile of Gunnera manicata L. extracts
}

\author{
Kristiane de Cássia Mariotti', Roselena Silvestri Schuh ${ }^{1, *}$, Jéssica de Matos Nunes ${ }^{2}$, Sabrina Pinto \\ Salamoni ${ }^{3}$, Gabriela Meirelles ${ }^{2}$, Fabiano Barreto ${ }^{4}$, Gilsane Lino Von Poser ${ }^{1}$, Rodrigo Bustos Singer ${ }^{5}$, \\ Eliane Dallegrave ${ }^{6}$, Sueli Teresinha Van Der Sand ${ }^{3}$, Renata Pereira Limberger ${ }^{1}$
}

\begin{abstract}
${ }^{1}$ Laboratory of Analysis and Toxicological Research, Analysis Department, Faculty of Pharmacy, Federal University of Rio Grande do Sul, Porto Alegre, RS, Brazil, ${ }^{2}$ Raw Material Production Department, Faculty of Pharmacy, Federal University of Rio Grande do Sul, Porto Alegre, RS, Brazil, ${ }^{3}$ Microbiology Department, Basic Health Sciences Institute, Federal University of Rio Grande do Sul, Porto Alegre, RS, Brazil, ${ }^{4}$ National Agricultural Laboratory of Rio Grande do Sul, Porto Alegre, RS, Brazil, ${ }^{5}$ Botany Department, Laboratory of Cryptogamae Systematic, Federal University of Rio Grande do Sul, Porto Alegre, RS, Brazil, ${ }^{6}$ Toxicology Information Center of Rio Grande do Sul, State Foundation for Production and Health Research, Porto Alegre, RS, Brazil
\end{abstract}

\begin{abstract}
Gunnera perpensa L. (Gunneraceae) is a native South African plant widely used in traditional medicine as an antibacterial and antifungal. In southern Brazil there is the native species called Gunnera manicata $\mathrm{L}$. that also belongs to the Gunneraceae. Nevertheless, there is no information about chemical and pharmacological properties of South American Gunnera species. Therefore this study aimed at assessing the phytochemical and pharmacological profiles of aqueous and methanol Brazilian $G$. manicata extracts. The results showed that antimicrobial activity in an agar diffusion assay was effective against Staphylococcus aureus and Candida albicans. Phenolic compounds were investigated by liquid chromatography coupled with a tandem mass spectrometer (LC-MS/MS) and all extracts presented gallic acid and only the methanol extract obtained from the leaves exhibited hyperoside. Rutin, quercetin and chlorogenic acid were not found in the samples analysed. Total phenolic content was higher in methanol extract and total flavonoid content was low in all extracts. Antioxidant activity was evaluated by the 2,2-diphenyl-1-picryl-hydrazyl (DPPH) radical test, and all samples presented good to moderate antioxidant activity. These results encourage complementary studies on the chemical composition of the plant extracts focusing on isolation and structure elucidation of their active compounds.
\end{abstract}

Uniterms: Gunnera manicata L./phytochemistry. Gunnera manicata L./pharmacognosy. Gunneraceae/ pharmacognosy. Gunnera manicata L./extracts/antimicrobial effect. Gunnera manicata L./extracts/ antioxidant activity. Gunnera manicata L./extracts/antimicrobial assay.

Gunnera perpensa L. (Gunneraceae) é uma planta nativa do sul da África utilizada na medicina tradicional como antibiótico e antifúngico. Gunnera manicata L. é uma planta nativa do sul do Brasil também da família Gunneraceae e, apesar disso, não há informações sobre suas propriedades químicas e farmacológicas. Assim, o objetivo deste estudo foi avaliar o perfil fitoquímico e farmacológico dos extratos aquoso e metanólico de G. manicata. Os resultados do ensaio microbiológico de difusão em ágar demonstraram que os extratos testados foram ativos contra Staphylococcus aureus e Candida albicans. A presença de compostos fenólicos foi investigada pela técnica de Cromatografia Líquida acoplada a espectrômetro de massas em Tandem (CL-EM/EM). Em todas as amostras analisadas verificou-se a presença de ácido gálico e somente o extrato metanólico das folhas apresentou hiperosídeo. Rutina, quercetina e ácido clorogênico não foram encontrados. O conteúdo total de compostos fenólicos foi maior nos extratos metanólicos e o conteúdo de flavonóides totais foi baixo em todos os extratos. A atividade antioxidante foi avaliada pelo

\footnotetext{
*Correspondence: R. S. Schuh. Laboratório de Análises e Pesquisas Toxicológicas, Faculdade de Farmácia, Universidade Federal do Rio Grande do Sul. Av. Ipiranga, 2752, 90610-000 - Porto Alegre - RS, Brasil. Tel.: +55 51 3308-5297; fax: +55 51 3308-5437. E-mail: rose_schuh@yahoo.com.br
} 
teste da atividade do radical 2,2-diphenyl-1-picril-hidrazil (DPPH) e todas as amostras apresentaram boa a moderada atividade antioxidante. Esses resultados encorajam estudos complementares da composição química dos extratos com foco no isolamento e na elucidação estrutural dos compostos ativos.

Unitermos: Gunnera manicata L./fitoquímica. Gunnera manicata L./farmacognosia. Gunneraceae/ farmacognosia. Gunnera manicata L./extratos/efeito antimicrobiano. Gunnera manicata L./extratos/ atividade antioxidante. Gunnera manicata L./extratos/ensaio antimicrobiano.

\section{INTRODUCTION}

Gunnera (Gunneraceae) species are mainly found in the Southern hemisphere. In Southern Africa, Gunnera perpensa $\mathrm{L}$. is a medicinal plant used by traditional healers for the treatment of venereal diseases. These medicinal properties are due to the presence of antibacterial and antifungal compounds (Buwa, 2005). Rural inhabitants of the Eastern Cape Province use leaves of this plant as wound dressing (Drewes et al., 2005). It is also a traditional herbal medicine used by many South African women as antenatal medication or to induce or augment labour, to treat female infertility, expel the placenta and/ or prevent post-partum haemorrhage (Kaido et al., 1997; Kahn et al., 2004). The Gunnera manicata L. species is a native plant from Southern Brazil, it grows at high altitudes (above $900 \mathrm{~m}$ ) on the border between the states of Rio Grande do Sul and Santa Catarina, in a region locally known as "Aparados da Serra". Despite being appreciated as an ornamental plant and belonging to the same family (Gunneraceae) as G. perpensa (an extensively studied species), little data is found on G. manicata in scientific literature, and this includes the absence of anti-estrogenic activity (Mariotti et al., 2011a) and the acute toxicity of aqueous extracts of $G$. manicata against Wistar rats, that showed a high margin of safety (Mariotti et al., 2011b).

Considering these data, new approaches to this species are necessary. Therefore, this work aimed at evaluating pharmacological and phytochemical profiles of G. manicata. For this, the antimicrobial properties, antioxidant potential, total phenol content (TPC), total flavonoid content (TFC) and the presence of phenolic compounds by liquid chromatography coupled with tandem mass spectrometry (LC-MS/MS) were investigated. The results obtained represent the first analysis of pharmacological and phytochemical proprieties of G. manicata.

\section{MATERIAL AND METHODS}

\section{Plant material}

Roots and leaves of G. manicata were collected in the "Aparados da Serra" region, Southern Brazil, and identified by Rodrigo B. Singer. A voucher specimen (R.B. Singer s. n., Serra da Rocinha, January 15th, 2009) is deposited at the ICN - Department of Botany - UFRGS herbarium in Porto Alegre, Brazil.

\section{Preparation of extracts}

The aqueous extracts were made with dried roots or leaves extracted in a water bath at $50{ }^{\circ} \mathrm{C}$ during 3 hours (ARE50/ALE50 Aqueous Roots Extracts and Aqueous Leaves Extracts, respectively) or at $100^{\circ} \mathrm{C}$ during 1 hour (ARE 100/ALE 100 Aqueous Roots Extracts and Aqueous Leaves Extracts, respectively). The methanol extract was obtained by static maceration during 24 hours at room temperature (MRE/MLE - Methanol Roots Extracts and Methanol Leaves Extract, respectively). These extracts were collected, filtered, concentrated to dryness under reduced pressure and the residue was maintained at $4 \pm 2$ ${ }^{\circ} \mathrm{C}$ until the experiments were performed.

\section{Antimicrobial activity assay}

The antimicrobial activities of $G$. manicata extracts were determined by the agar diffusion method. The dried plant extracts were dissolved in water or methanol to a final concentration of $25.0 \mathrm{mg} / \mathrm{ml}$ and filtered through $0.22 \mu \mathrm{m}$ Millipore filters for sterilization. The antibacterial activities were screened with the extracts against Grampositive bacteria (Staphylococcus aureus ATCC 25923, Streptococcus pyogenes ATCC 8668, Bacillus subtilis ATCC 19659), Gram-negative bacteria (Escherichia coli ATCC 25922 and Pseudomonas aeruginosa ATCC 25933) and yeast (Candida albicans ATCC 10231). By means of a sterile cork borer, $9 \mathrm{~mm}$ wells were punctured in plates containing Muller-Hinton agar previously seeded with one of the test microorganisms (the final inoculum size was $1 \times 10^{8} \mathrm{CFU} / \mathrm{mL}, 0.5$ MacFarland), then $100 \mu \mathrm{L}$ of extract were added in each well. The Petri dishes were incubated at $8-10^{\circ} \mathrm{C}$ for $16 \mathrm{~h}$ for the diffusion of the bioactive compounds. After this period, the incubation continued at $28-37^{\circ} \mathrm{C}$ for $24 \mathrm{~h}$. Then, the inhibition zones were measured. The diameters of inhibition zones were 
used as a measure of antimicrobial activity. Assays were carried out in triplicate. A Gentamicin $10 \mu \mathrm{g}$ disk was used as positive control for bacteria and a Nystatin $100 \mu \mathrm{g}$ disk for yeast.

\section{Spectrophotometric DPPH assay}

Antioxidant activity against the stable radical DPPH was evaluated quantitatively by spectrophotometric measures of the consumption of this radical in the presence of antioxidants (Brand-Williams et al., 1995). Briefly, aliquots of aqueous or methanol solution of test samples at different concentrations were added to a DPPH ethanolic solution (molar absorption coefficient $517 \mathrm{~nm}$ : $11,500 \mathrm{M} \mathrm{cm}^{-1}$ ). The DPPH solution absorbance began to be measured immediately after mixing the samples. The decrease in absorbance was monitored at $\lambda=517 \mathrm{~nm}$ during 600 seconds with measurements every 1 second, at $25{ }^{\circ} \mathrm{C}$. For the evaluation of the antioxidant potential, experimental data (kinetic profiles of DPPH decay) were adjusted in terms of the percentage reduction of DPPH and Q, sometimes referred to as "inhibition" or "quenching", which is defined by:

$$
\mathrm{Q}=100(\mathrm{Ao}-\mathrm{Ac}) / \mathrm{Ao}
$$

where Ao is the initial absorbance and Ac is the value of the absorbance of the added sample at concentration c. This value of Ac should be that in the cuvette in the absence of any DPPH, and should take into account the dilution of the original sample solution by the added DPPH solution (Molyneux, 2004). The experiments were performed in triplicate and results were expressed as the average of $\mathrm{A} / \mathrm{Ao}$ and the $\mathrm{IC}_{50}$ (concentration of $50 \% \mathrm{DPPH}$ radical bleaching) was calculated for each sample. Ethanol was used as a blank in the spectrophotometer. Quercetin was used as reference.

\section{Phytochemical profile}

\section{Determination of total phenolic content}

Total phenolic content (TPC) was assayed using the Folin-Ciocalteu (Singleton, Rossi, 1965) modified method. Appropriate dilutions of the samples were oxidized with $0.2 \mathrm{~N}$ Folin-Ciocalteu reagent (Merck Darmstadt, Germany; $2 \mathrm{~N}$ diluted 10-fold) and after 5 min the reaction was neutralized with saturated sodium carbonate $\left(75 \mathrm{gL}^{-1}\right)$. After $30 \mathrm{~min}$ of reaction at room temperature the absorbance of the resulting blue color was measured at $765 \mathrm{~nm}$ wavelength with an ultraviolet-visible Biospectro SP-220 spectrophotometer. TPC was expressed as milligrams of quercetin equivalent per $100 \mathrm{mg}$ of dry extract $\left(\mathrm{QE}\left(100 \mathrm{mgDE}^{-1}\right)\right.$ through a calibration curve for quercetin (Ivanova et al., 2005), with concentrations ranging from 50 to $500 \mathrm{mg} \mathrm{mL}^{-1}\left(\mathrm{r}^{2}>0.99\right)$.

\section{Determination of total flavonoid content (TFC)}

The total flavonoid content in aqueous and methanol extracts was determined according to the German Pharmacopoeia method (DAB 9) general method, using $\mathrm{AlCl}_{3} 1 \%(\mathrm{~m} / \mathrm{v})$.

Each plant extract $\left(1.0 \mathrm{~mL}\right.$ of $\left.1: 100 \mathrm{~g} \mathrm{~mL}^{-1}\right)$ was separately mixed with $7.0 \mathrm{~mL}$ of methanol prior to $2.0 \mathrm{~mL}$ of $1 \%$ aluminum chloride. The calibration curve was performed with methanol quercetin solutions at concentrations of 1.0 to $8.0 \mu \mathrm{g} \mathrm{mL}^{-1}(\mathrm{y}=0.078 \mathrm{x}+0.0065$, $\left.\mathrm{r}^{2}=0.998\right)$. Absorption of these sample solutions was measured after $10 \mathrm{~min}$ at $420 \mathrm{~nm}$ wavelength with an ultraviolet-visible Biospectro SP-220 spectrophotometer. The TFC was calculated from the equation:

$$
\mathrm{C}=\frac{\mathrm{AFd}}{\mathrm{m} \mathrm{E}_{1 \mathrm{~cm}}^{1 \%}}
$$

where " $C$ " is the TFC content expressed as grams of quercetin per $100 \mathrm{~g}$ of sample, " $\mathrm{A}$ " is the measured absorption (A.U.), "Fd" is a dilution factor, " $\mathrm{m}$ " is the sample weight (g) and " $\mathrm{E}^{1 \%}{ }_{1 \mathrm{~cm}}$ " is the specific absorption of quercetin - $\mathrm{AlCl}_{3}$ complex. Each analysis was performed in triplicate.

\section{LC-MS/MS analysis}

The analysis was performed by direct infusion in a Sciex API 5000 triple stage quadrupole mass spectrometer (Applied Biosystems, Foster City, CA, USA). The mobile phase used in the infusion procedure was mixed with solvent A $(0.1 \%$ formic acid) and solvent B (acetonitrile). The flow rate of the syringe was $10 \mu 1 \mathrm{~min}^{-1}$. The ions were monitored in full scan in positive and negative mode, nitrogen was used for both nebulizer and collision gas. The optimized parameters were: declustering potential $100 \mathrm{eV}$, entrance potential $10 \mathrm{eV}$, collision energy $35 \mathrm{eV}$, and collision cell exit potential $10 \mathrm{eV}$. The fragmentation profile was obtained from the selection of a pattern ion and monitored in MS2 mode. The target ions monitored were 169 for gallic acid; 301 for quercetin; 353 for chlorogenic acid; 463 for hyperoside and 609 for rutin (Tomás-Barberán, 2001; Clifford, 2003).

\section{Data analysis}

The $\mathrm{IC}_{50}$ values were determined by linear regression 
TABLE I - Antimicrobial activity of G. manicata extracts $25 \mathrm{mg} \mathrm{mL}^{-1}$ (inhibition zones in diameter (mm))

\begin{tabular}{|c|c|c|c|c|c|c|c|c|}
\hline Microorganism species & ARE100 & ARE100 & ARE50 & ALE50 & MLE & MRE & GEN & NYS \\
\hline Bacillus subtilis ATCC 19659 & - & - & - & - & - & 17 & 26 & - \\
\hline $\begin{array}{l}\text { Staphylococcus aureus } \\
\text { ATCC 25923a }\end{array}$ & - & - & - & 20 & - & - & 21 & - \\
\hline $\begin{array}{l}\text { Streptococcus pyogenes } \\
\text { ATCC } 8668\end{array}$ & - & - & - & 16 & - & - & 24 & - \\
\hline Escherichia coli ATCC $25922^{\mathrm{a}}$ & - & - & - & - & - & - & 23 & - \\
\hline $\begin{array}{l}\text { Pseudomonas aeruginosa } \\
\text { ATCC } 25933\end{array}$ & - & - & - & - & - & - & 20 & - \\
\hline Candida albicans ATCC 10231a & - & - & - & - & 18 & 16 & - & 20 \\
\hline
\end{tabular}

*A dash (-) indicates no antimicrobial activity. The diameter of the inhibition zone is expressed in millimeters (mL). Gentamicin $10 \mu \mathrm{g}$ and nystatin $100 \mu \mathrm{g}$ served as controls for bacteria and fungi, respectively.

between the DPPH radical bleaching and sample concentration. All results were obtained from three independent experiments and given as mean \pm standard deviation (SD). The correlation between the antioxidant activity and total phenolic content was also determined using the linear regression equation.

\section{RESULTS AND DISCUSSION}

G. manicata is a known and appreciated ornamental plant native to Southern Brazil. This study was performed taking these facts into account and the absence of scientific information about pharmacological and phytochemical aspects. For both, different extracts were tested against specific target microorganisms utilized as taxonomical representatives in an initial screening. The results of antimicrobial activity were assessed qualitatively by the presence or absence of inhibition zones. Different extracts at $25 \mathrm{mg} \mathrm{mL}^{-1}(\mathrm{w} / \mathrm{v})$ obtained from G. manicata demonstrated these activities. As can be seen in Table I, ALE50 extracts of G. manicata showed activity against $S$. pyogenes and $S$. aureus, one of the most persistent infectious microorganisms commonly found in nosocomial infections (Steenkamp, 2004). MRE and MLE exhibited activity against $C$. albicans, a significant cause of infection in humans. Several of the more commonly isolated microorganisms among these species are less susceptible to commonly used azole antifungal drugs, which makes it very difficult to treat them effectively (Coleman et al., 1998).

None of the extracts tested exhibited activity against gram-negative bacteria. This result may be explained because these microorganisms have an outer membrane consisting of lipoproteins and lipopolysaccharides, which is selectively permeable and thus regulates access to the underlying structures. This renders the Gram-negative bacteria generally less susceptible to plant extracts than the Gram-positive bacteria (Samec et al., 2009).

In the assessment of antibacterial and antifungal (yeast) activities, G. perpensa, a native plant of South Africa, showed higher activity for the leaves compared with the stems and roots (Drewes et al., 2005), and the same occurred with G. manicata. While the activities recorded for the leaf extract were not impressive, $G$. perpensa inhibition of $S$. aureus was good (Drewes et al., 2005), corroborating the results of G. manicata for this Gram-positive bacteria.

The results of the antioxidant activity analysis, TPC and TFC are shown in Table II.

TABLE II - Total Flavonoid Content (TFC) ( $\mathrm{g} \%$ of extract), Total Phenolic Content (TPC) (QE(100 $\left.\mathrm{mg} \mathrm{DE}^{-1}\right)$ and $\mathrm{IC}_{50}$ values $(\mu \mathrm{g}$ $\mathrm{mL}^{-1}$ ) from aqueous and methanol G. manicata extracts

\begin{tabular}{lccc}
\hline $\begin{array}{l}\text { G. manicata } \\
\text { extracts }\end{array}$ & TFC & TPC & $\mathrm{IC}_{50}$ \\
\hline ALE50 & $1.69 \pm 0.0005$ & $13.42 \pm 1.06$ & $28.17 \pm 0.80$ \\
ARE50 & $1.59 \pm 0.002$ & $19.47 \pm 1.53$ & $15.68 \pm 0.36$ \\
ALE100 & $2.85 \pm 0.057$ & $28.39 \pm 1.47$ & $12.47 \pm 0.16$ \\
ARE100 & $0.31 \pm 0.002$ & $28.11 \pm 1.61$ & $15.92 \pm 0.38$ \\
MLE & $0.53 \pm 0.004$ & $11.70 \pm 1.38$ & $39.89 \pm 0.38$ \\
MRE & $3.85 \pm 0.002$ & $30.13 \pm 1.24$ & $33.93 \pm 0.61$ \\
\hline
\end{tabular}

In the analysis of antioxidant potential, the ability of samples to scavenge the DPPH radical was determined based on their concentrations providing 50\% inhibition $\left(\mathrm{IC}_{50}\right)$. ALE100, ARE100 and ARE50 exhibited strong antioxidant activity. MRE and MLE showed moderate antioxidant potential, good antimicrobial and antifungal 

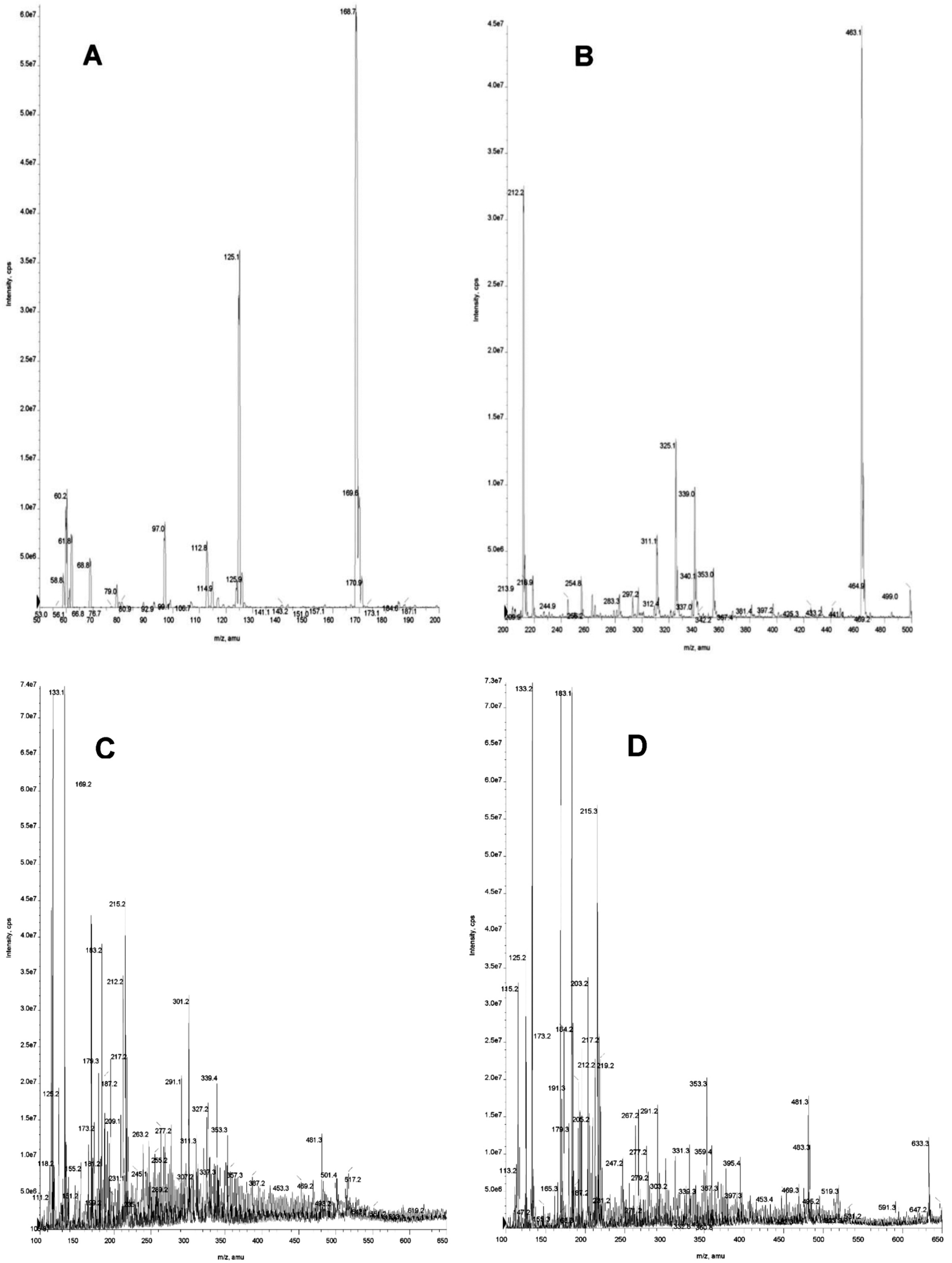

FIGURE 1 - Phenolic compounds found in the investigation by LC-MS/MS (A. Gallic acid analysis - target ion 169; B. Hyperoside analysis - target ion 463; C. ALE100 analysis, an example of an extract containing gallic acid; D. MLE analysis, the only extract that contained hyperoside). 
activities and a high TPC. These data may indicate a correlation between antimicrobial activities and the amount of phenolic compounds.

G. manicata antioxidant activity results were similar to those obtained with G. perpensa, which showed possible scavenging activity in a concentration dependent manner, while aqueous extracts demonstrated higher activity than methanol extracts (Steenkamp, 2004).

The TPC of plant extracts was determined using a colorimetric assay method. Results were expressed as quercetin equivalent per $100 \mathrm{mg}$ of dry extract. The amounts of TPC were higher in MRE, followed by ARE100 and ALE100. In statistical analysis, there was no linear correlation between TPC and antioxidant activity $\left(r^{2}=0.2316\right)$.

In the analysis of TFC, all samples demonstrated low flavonoid content contrasting with the values of TPC.

In this work, no linear correlation was found between TPC and antioxidant potential. This relationship reported in the literature is somewhat confusing. Some investigators have proposed the existence of a close correlation between antioxidant activity and phenolic compound content of the extracts obtained from various natural sources. Others did not correlate them merely to each other and propose and suggest that a wide range of compounds, such as phenolics, peptides, organic acids and other components contribute to the antioxidant activity (Ebrahimabadi et al., 2010).

The potential antioxidant capability of the other Gunneraceae species, G. Perpensa, has been established (Simelane et al., 2010). It seems that G. perpensa contains compounds that might improve the action of natural dietary antioxidants. The relatively high total polyphenol content and the significant total antioxidant capacity could possibly contribute to $G$. perpensa antioxidant properties (Simelane et al., 2010).

In the investigation of five different phenolic compounds by LC-MS/MS, all extracts present gallic acid and only methanol leaves extract exhibited hyperoside. Rutin, quercetin and chlorogenic acid were not found in the samples analyzed.

In Figure 1.C the ALE100 analysis is shown as an example of a gallic acid positive extract, since all the extracts presented this compound. MLE analysis can be seen in Figure 1.D as the only G. manicata extract composed by hyperoside.

Flavonoids constitute the largest group of plant phenolics (Balasundram et al., 2006) and their antimicrobial effects have been extensively researched (Samec et al., 2009). Considering these data, the presence of flavonoids was investigated. As result, low TFC was found despite the large amount of TPC in the sample analyzed. These data suggest that another class of phenolic compounds, such as hydrolyzed tannins, for example, may be responsible for the amount of TPC. This fact may be partially confirmed by the LC-MS/MS analysis, which showed the presence of gallic acid in all extracts.

\section{CONCLUSION}

These findings leave open the possibility of further studies using G. manicata as a source for the discovery of novel leader structures to be used in drug production, and also for the development of active plant extracts that can be used for treatment of various diseases. The results found in this work encourage complementary studies on the chemical composition of the plant extracts focusing on isolation and structure elucidation of their active components and evaluation of the biological activity of each compound separately.

\section{ACKNOWLEDGEMENTS}

The authors would like to thank CNPq for financial support.

\section{REFERENCES}

AO, C.; LI, A.; ELZAAWELY, A.A.; XUAN, T.D.; TAWATA, S. Evaluation of antioxidant and antibacterial activities of Ficus microcarpa L. fil. extract. Food Control, v.19, p.940948, 2008.

ARBO, M.D.; FRANCO, M.T.; LARENTIS, E.R.; GARCIA, S.C.; SEBBEN, V.C; LEAL, M.B.; DALLEGRAVE, E.; LIMBERGER, R.P. Screening for in vivo (anti)estrogenic activity of ephedrine and $p$-synephrine and their natural sources Ephedra sinica Stapf. (Ephedraceae) and Citrus aurantium L. (Rutaceae) in rats. Arch. Toxicol., v.83, p.9599, 2009.

BALASUNDRAM, N.; SUNDRAM, K.; SAMMAN, S. Phenolic compounds in plants and agri-industrial byproducts: antioxidant activity, occurrence, and potential uses. Food Chem., v.99, p.191-203, 2006.

TOMÁS-BARBERÁN, F.A.; GIL, M.I.; CREMIN, P.; WATERHOUSE, A.L.; HESS-PLERCE, B.; KADER, A.A. HPLC-DAD-ESIMS analysis of phenolic compounds in nectarines, peaches and plums. J. Agric. Food Chem., v.19, p.4748-4760, 2001. 
BRAND-WILLIAMS, W.; CUVELIER, M.E.; BERSET, C. Use of a free radical method to evaluate antioxidant activity. LWT - Food Sci. Technol., v.28, p.25-30, 1995.

BUWA, L.V.; VAN STADEN, J. Antibacterial and antifungal activity of traditional medicinal plants used against venereal diseases in South África. J. Ethnopharmacol., v.103, p.139142, 2006.

CLINFFORD, H.; JOHNSTON, K.L.; KNIGHT, S.; KUHNERT, N. Hierarchical scheme for LC-MS identifications of chlorogenic acids. J. Agric. Food Chem., v.51, p.29002911, 2003.

COLEMAN, D.C.; RINALDI, M.G.; HAYNES, K.A.; REX, J.H.; SUMMERBELL, R.C.; ANAISSIE, E.J.; LI, A.; SULLIVAN, D.J. Importance of Candida species other than Candida albicans as opportunistic pathogens. Med. Mycol., v.36, suppl.1, p.156-165, 1998.

DREWES, S.E.; KHAN, F.; Van VUUREN, S.F.; VILJOEN, A.M. Simple 1,4-benzoquinones with antibacterial activity from stems and leaves of Gunnera perpensa. Phytochemistry, v.66, p.1812-1816, 2005.

EBRAHIMABADI, A.H.; EBRAHIMABADI, E.H.; DJAFARIBIDGOLI, Z.; KASHI, F.J.; MAZOOCHI, A.; BATOOLI, H. Composition and antioxidant and antimicrobial activity of the essential oil and extracts of Stachys inflata Benth from Iran. Food Chem., v.119, p.452-458, 2010.

FUMAGALI, E.; GONÇALVES, R.A.C.; MACHADO, M.F.P.S.; VIDOTI, G.J.; OLIVEIRA, A.J.B. Produção de metabólitos secundários em cultura de células e tecidos de plantas: o exemplo dos gêneros Tabernaemontana e Aspidosperma. Rev. Bras. Farmacogn., v.18, p.627-641, 2008.

IVANOVA, A.; MIKHOVA, B.; NAJDENSKI, H.; TSVETKOVA, I.; KOSTOVA, I. Antimicrobial and cytotoxic activity of Ruta graveolens. Fitoterapia, v.76, p.344-347, 2005.

KHAN, F.; PETER, X.K.; MACKENZIE, R.M.; KATSOULIS, L.; GEHRING, R.; MUNRO, O.Q.; Van HEERDEN, F.R.; DREWES, S.E. Venusol from Gunnera perpensa: structural and activity studies. Phytochemistry, v.65, p.1117-1121, 2004.
LANGFIELD, R.D.; SCARANO, F.J.; HEITZMAN, M.E.; KONDO, M.; HAMMOND, G.B.; NETO, C.C. Use of a modified microplate bioassay method to investigate antibacterial activity in the Peruvian medicinal plant Peperomia galioides. J. Ethnopharmacol., v.94, p.279281, 2004.

MARIOTTI, K.C.; BARRETO, F.; SCHMITT, G.C.; ZANCANARO, I.; DALLEGRAVE, E.; SINGER, R.B.; LEAL, M.B.; LIMBERGER, R.P. Study of acute toxicity and investigation of the presence of $\beta-\mathrm{N}$-methylaminoL-alanine in the Gunnera manicata L. a species native to Southern Brazil. Braz. J. Pharm. Sci., v.47, n.3, p.623-628, 2011a.

MARIOTTI, K.C.; BARRETO, F.; SCHMITT, G.C.; ZANCANARO, I.; DALLEGRAVE, E.; SINGER, R.B.; LEAL, M.B.; LIMBERGER, R.P. Evaluation of antiestrogenic or estrogenic activities of aqueous root extracts of Gunnera manicata L. Braz. J. Pharm. Sci., v.47, n.3, p.601-604, $2011 b$.

MCGAW, L.J.; ELOFF, J.N. Ethnoveterinary use of southern African plants and scientific evaluation of their medicinal properties. J. Ethnopharmacol., v.119, p.559-574, 2008.

MOLYNEUX, P. The use of the stable free radical diphenylpicrylhydrazyl (DPPH) for estimating antioxidant activity. Songklanakarin J. Sci. Technol., v.26, p.211-219, 2004.

ODUM, J.; LEFEVRE, P.A.; TITTENSOR, S.; PATON, D.; ROUTLEDGE, E.J.; BERESFORD, N.A.; SUMPTER, J.P.; ASHBY, J. The rodent uterotrophic assay: critical protocol features, studies with phenols, and comparison with a yeast estrogenicity assay. Regul. Toxicol. Pharmacol., v.25, p.176-188, 1997.

ŠAMEC, D.; GRUZ, J.; STRNAD, M.; KREMER, D.; KOSALEC, I.; JURIŠIC' GRUBEŠIC, R.; KARLOVIC', K.; LUCIC, A.; PILJAC-Z` EGARAC, J. Antioxidant and antimicrobial properties of Teucrium arduini L. (Lamiaceae) flower and leaf infusions (Teucrium arduini L. antioxidant capacity). Food Chem. Toxicol., v.48, p.113-119, 2010.

SIMELANE, M.B.C.; LAWAL, O.A.; DJAROVA, T.G.; OPOKU, A.R. In vitro antioxidant and cytotoxic activity of Gunnera perpensa L. (Gunneraceae) from South Africa. J. Med. Plants Res., v. 4, p.2181-2188, 2010. 
SINGLETON, V.L.; ROSSI, J.A. Colorimetry of total phenolics with phosphomolybdic-phosphotungstic acid reagents. Am. J. Enol. Vitic., v.16, p.144-158, 1965.

SOKMEN, A.; JONES, B.M.; ERTURK, M. The in vitro antibacterial activity of Turkish medicinal plants. $J$. Ethnopharmacol., v.67, p.79-86, 1999.

STEENKAMP, V.; MATHIVHA, E.; GOUWS, M.C.; VAN RENSBURG, C.E.J. Studies on antibacterial, antioxidant and fibroblast growth stimulation of wound healing remedies from South Africa. J. Ethnopharmacol., v.95, p.353-357, 2004.

TSHIKALANGE, T.E.; MEYER, J.J.M.; HUSSEIN, A.A. Antimicrobial activity, toxicity and the isolation of a bioactive compound from plants used to treat sexually transmitted diseases. J. Ethnopharmacol., v.96, p.515-519, 2005.
VELIOGLU, Y.S.; MAZZA, G.; GAO, L.; OOMAH, B.D. Antioxidant activity and total phenolics in selected fruits, vegetables and grain products. J. Agric. Food Chem., v.46, p.4113-4117, 1998.

VAN VUUREN, S.F. Antimicrobial activity of South African medicinal plants. J. Ethnopharmacol., v.119, p.462-472, 2008.

Received for publication on $29^{\text {th }}$ May 2013 Accepted for publication on $06^{\text {th }}$ September 2013 